\title{
Complications of a non-native oyster introduction: facilitation of a local parasite
}

\author{
Melanie J. Bishop ${ }^{1,3, *}$, Ryan B. Carnegie ${ }^{2}$, Nancy A. Stokes ${ }^{2}$, Charles H. Peterson ${ }^{1}$, \\ Eugene M. Burreson ${ }^{2}$ \\ ${ }^{1}$ University of North Carolina at Chapel Hill, Institute of Marine Sciences, 3431 Arendell Street, Morehead City, \\ North Carolina 28557, USA \\ ${ }^{2}$ Virginia Institute of Marine Science, The College of William and Mary, Route 1208 Greate Road, Gloucester Point, \\ Virginia 23062, USA \\ ${ }^{3}$ Present address: Department of Environmental Sciences, University of Technology Sydney, PO Box 123, Broadway, \\ New South Wales 2007, Australia
}

\begin{abstract}
Among the risks of introducing non-native species to novel environments is the possibility that the non-native might serve as a reservoir for enzootic pathogens formerly at low abundance. The recent identification of Bonamia sp. in previously uninfected non-native Suminoe oysters deployed to Bogue Sound, Morehead City, North Carolina, USA, raises serious concerns about the oyster's ability to act as a reservoir for the parasite, not formerly known along the east coast of the USA. To assess the current distribution of the Bonamia sp. parasite and its environmental tolerances, non-reproductive triploid Suminoe oysters, certified as uninfected, were deployed at 5 high salinity sites across North Carolina, chosen because of their similarity to the Bogue Sound site, and along a salinity gradient radiating from Morehead City Port, at which the parasite is known to occur. Screening of 2 oyster cohorts failed to detect the Bonamia sp. parasite beyond the immediate vicinity of Morehead City port. At the port, infection was almost entirely confined to small ( $<40 \mathrm{~mm}$ shell height) oysters. These results suggest that the parasite, which is genetically similar to Australasian species, is a recent ballast water introduction through Morehead City Port and that its spread may be dependent on the availability of suitable hosts in high salinity environments. Clearly, the proposed introduction of the Suminoe oyster to the mid-Atlantic coast of the USA represents considerable economic and ecological risk and should not proceed without further study to obtain better estimates of likely effects.
\end{abstract}

KEY WORDS: Non-native $\cdot$ Ballast water introduction $\cdot$ Facilitation $\cdot$ Oyster $\cdot$ Proliferation $\cdot$ Parasite

\section{INTRODUCTION}

The intentional introduction of non-native species to novel environments for aquaculture or to supplement degraded native fisheries entails significant economic and ecological risks. Although many plants and animals have been successfully introduced for culture, some exotic species do not survive where they are introduced, resulting in large economic losses (Williamson \& Fitter 1996). Others become pests, displacing native species, changing the composition of native communities, and influencing the performance of ecosystems (e.g. Stachowicz et al. 1999, 2002, Grosholz et al. 2000). There are countless examples of species that have acted as vectors for the spread of hitch-hiking species that serve as predators, competitors and pathogens to natives (Ruiz et al. 2000). An additional yet seldom considered risk is the possibility that non-native species might serve as reservoirs for enzootic pathogens formerly at low abundance, facilitating their proliferation to levels that threaten native species.

Because of the potential economic and ecological risks of intentional introductions, managers should 
carefully weigh prospective negative environmental effects against anticipated economic, social, and ecological benefits prior to any introduction. This requires a capacity to correctly predict the broad ecosystem consequences of the introduction - a challenge to the discipline of conservation ecology (Ehrlich 1989, Cohen \& Carlton 1998). Although the outcome of many introductions may be predicted from knowledge of the non-native's biology within its native range, the environment to which the species is to be introduced, and the outcome of any previous introductions of the species elsewhere (e.g. Ehrlich 1989), successful forecast is not always the case (see Branch \& Steffani 2004). Small-scale field trials with non-reproductive individuals may provide valuable insights not gleaned through a more theoretical approach.

The Suminoe oyster Crassostrea ariakensis, a native of China, Korea, and Japan, is currently being considered for introduction to the mid-Atlantic coast of the USA to supplement diminished native oyster fishery resources (NRC 2004). Years of over-harvesting and habitat destruction, coupled with recent mortality from the oyster parasites Haplosporidium nelsoni and Perkinsus marinus, have reduced Chesapeake Bay and North Carolina populations of the eastern oyster Crassostrea virginica by over $99 \%$ since the start of the 20th century (Rothschild et al. 1994, Frankenberg 1995). To assess the likely success of the proposed Suminoe oyster introduction, a number of small-scale, in-water trials with non-reproductive triploid $C$. ariakensis have been performed in North Carolina and Virginia. The first of these indicated rapid rates of growth and high survival of the non-native at the low-medium salinities (15 to $25 \mathrm{ppt}$ ) found throughout the Chesapeake Bay and Pamlico Sound (Calvo et al. 2001, Grabowski et al. 2004).

Despite early success with culture of Crassostrea ariakensis in mid-Atlantic waters, recent (2003) trials in North Carolina produced more troublesome results. In early August and early September 2003, $>73 \%$ of $C$. ariakensis from 2 separate spawns died within $5 \mathrm{wk}$ of transfer to high salinity (35 ppt) Bogue Sound, Morehead City, North Carolina, USA (Burreson et al. 2004). Meanwhile, oysters at a low salinity $(<10 \mathrm{ppt})$ site in Pamlico Sound, North Carolina, had low mortality $(\sim 1 \%)$, as did C. ariakensis held at Gloucester Point, Virginia. Histopathological evaluation of 4 moribund C. ariakensis from the August 2003 mortality event revealed 4 infections ( 3 heavy in intensity) by what appeared to be a Bonamia species. Ten of eleven moribund C. ariakensis examined from the September 2003 mortality event had presumptive Bonamia sp. infections, 7 of them heavy (Burreson et al. 2004). Presumptive Bonamia sp. infections were also observed in late fall (October) in samples of a third transplant of $C$. ari- akensis to Morehead City. Parasites in this final transplant were confirmed to be a novel Bonamia sp., only distantly related to Bonamia ostreae (Burreson et al. 2004), a directly transmissible, intrahemocytic, microcell haplosporidian parasite present within naturalized Ostrea edulis populations in Maine (Barber \& Davis 1994, Friedman \& Perkins 1994). The parasite was not detected in oyster broodstock or in seed prior to transfer.

Since this first detection of Bonamia sp. in Crassostrea ariakensis, the C. ariakensis-pathogenic Bonamia sp. has also been identified in Bogue Sound in the small native oyster Ostreola equestris (Carnegie et al. 2005). The identification of Bonamia sp. in C. ariakensis and $O$. equestris, the latter found in high salinity waters from North Carolina south to the Gulf states and West Indies (Wells 1961, Galtsoff \& Merrill 1962), raises serious questions as to the economic and ecological risks associated with the proposed introduction of C. ariakensis to the mid-Atlantic coast. Large economic and ecological losses could result from introduction of the Suminoe oyster if (1) the parasite has similar environmental tolerances to the oyster and causes mortality throughout the oyster's range, and/or (2) the non-native oyster facilitates local proliferation and spread of the parasite.

Initial in-water trials of Crassostrea ariakensis did not detect $C$. ariakensis-pathogenic Bonamia sp. outside of the Morehead City area. Screening of triploid C. ariakensis deployed at 15 locations across Maryland, Virginia and North Carolina only detected the parasite in the Newport River, a high salinity site less than $10 \mathrm{~km}$ from and tidally connected to the Bogue Sound site where the parasite was first discovered (Table 1). The absence of the parasite from a further 12 locations across Virginia and North Carolina was strongly suggested by low mortality of $C$. ariakensis at these sites (Calvo et al. 2001, Grabowski et al. 2004). The majority of $C$. ariakensis deployments (18 from 27) have, however, been at sites with salinities of less than 20 ppt. Thus, while the results may reflect an extremely limited distribution of Bonamia sp., they may alternatively reflect inhibition of the parasite at low salinities. Indeed, the recent detection of the parasite in Ostreola equestris at a high salinity site at Wilmington, North Carolina (R. B. Carnegie unpubl. data), suggests that the parasite might be more broadly distributed than once thought.

In this study we used deployments of triploid Crassostrea ariakensis oysters as sentinels to ascertain the distribution of C. ariakensis-pathogenic Bonamia sp. with respect to salinity and latitude. Specifically, we utilized a natural salinity gradient along waterways tidally connected to Bogue Sound sites to assess the salinity tolerance of the parasite. To assess the para- 
Table 1. Previous results of generic PCR screening for Bonamia spp. in Crassostrea ariakensis oysters deployed outside Bogue Sound, North Carolina, USA. MD: Maryland, VA: Virginia, NC: North Carolina. Bonamia spp. prevalence: no. infected oysters/no. oysters examined. Bold text indicates instances in which Bonamia spp. were detected

\begin{tabular}{|c|c|c|c|c|c|c|c|}
\hline \multirow[t]{2}{*}{ Location } & \multirow{2}{*}{$\begin{array}{l}\text { Salinity } \\
\text { (ppt) }\end{array}$} & \multicolumn{6}{|c|}{ Bonamia spp. prevalence } \\
\hline & & Nov 03 & Dec 03 & May 04 & Jul 04 & Aug 04 & Sep 04 \\
\hline Cambridge, MD & $5-18$ & & $0 / 30$ & & & & \\
\hline Gloucester Point, VA & $15-20$ & $0 / 29$ & & & & & \\
\hline Wachapreague, VA & $30-35$ & & $0 / 22$ & & & & \\
\hline Chincoteague, VA & $29-31$ & & & $0 / 30$ & $0 / 30$ & $0 / 30$ & $0 / 30$ \\
\hline Accoma, VA & $29-31$ & & & $0 / 30$ & $0 / 30$ & $0 / 30$ & $0 / 30$ \\
\hline Yorktown, VA & $15-17$ & & & $0 / 30$ & $0 / 30$ & $0 / 30$ & $0 / 30$ \\
\hline Hudgins, VA & $15-17$ & & & $0 / 30$ & $0 / 29$ & $0 / 30$ & $0 / 30$ \\
\hline Saxis, VA & $14-16$ & & & $0 / 30$ & $0 / 30$ & $0 / 30$ & $0 / 30$ \\
\hline Urbanna, VA & $12-14$ & & & $0 / 30$ & $0 / 30$ & $0 / 30$ & $0 / 30$ \\
\hline Burgess, VA & $11-13$ & & & $0 / 30$ & $0 / 30$ & $0 / 30$ & $0 / 30$ \\
\hline Kinsale, VA & $8-10$ & & & $0 / 30$ & $0 / 30$ & $0 / 30$ & $0 / 30$ \\
\hline Swan Quarter, NC & $10-15$ & & & $0 / 30$ & & $0 / 30$ & \\
\hline Nags Head, NC & 4 & & & & $0 / 60$ & & \\
\hline Walterslough, NC & $5-15$ & & & & $0 / 60$ & & \\
\hline Newport River, NC & $20-30$ & & & & $2 / 60$ & & \\
\hline
\end{tabular}

site's geographic distribution, we deployed oysters at sites of high salinity. Knowledge of the parasite's distribution, and salinity tolerance in particular, is essential if we are to predict the risk that the parasite poses to $C$. ariakensis culture and the risk, in turn, that $C$. ariakensis culture represents to native bivalves.

\section{MATERIALS AND METHODS}

Genetic triploid Crassostrea ariakensis produced in 2003 (spawn 3MXWCA03-2) and 2004 (spawn 3MXWCA04) at the Virginia Institute of Marine Sciences (VIMS) Aquaculture Genetics and Breeding Technology Center were used as sentinels for the Bonamia sp. parasite. A subsample of oysters was certified by histopathology in 2003 ( $\mathrm{n}=29$ ) and by histopathology and PCR in $2004(\mathrm{n}=60)$ to be free of Bonamia spp. and other pathogens prior to transfer from VIMS. Oysters from the 2003 cohort were maintained at a low (<10 ppt) salinity site (Swan Quarter, North Carolina) prior to the commencement of experiments. Bonamia spp. parasites had not previously been detected at this site and PCR confirmed that, at the time of experimental deployments, these oysters were Bonamia spp.-free $(\mathrm{n}=30)$. Oysters from the 2004 cohort were deployed directly upon receipt in North Carolina.

To ascertain the distribution of Bonamia sp. with respect to salinity, Crassostrea ariakensis were deployed along a natural gradient previously documented by Wells (1961). From the mouth of the Newport River at Bogue Sound, up-river through Core Creek and into the Neuse River estuary, salinity decreases from 35 ppt to around 15 to 22 ppt (dependent on recent rainfall). A single rack of oysters was deployed at each of 8 positions along the salinity gradient on 23 July 2004 (Fig. 1). Each steel rack was 0.8 m

Fig. 1. Location of study sites within high salinity sounds and along Bogue Sound-Neuse River salinity gradient (inset), North Carolina, USA

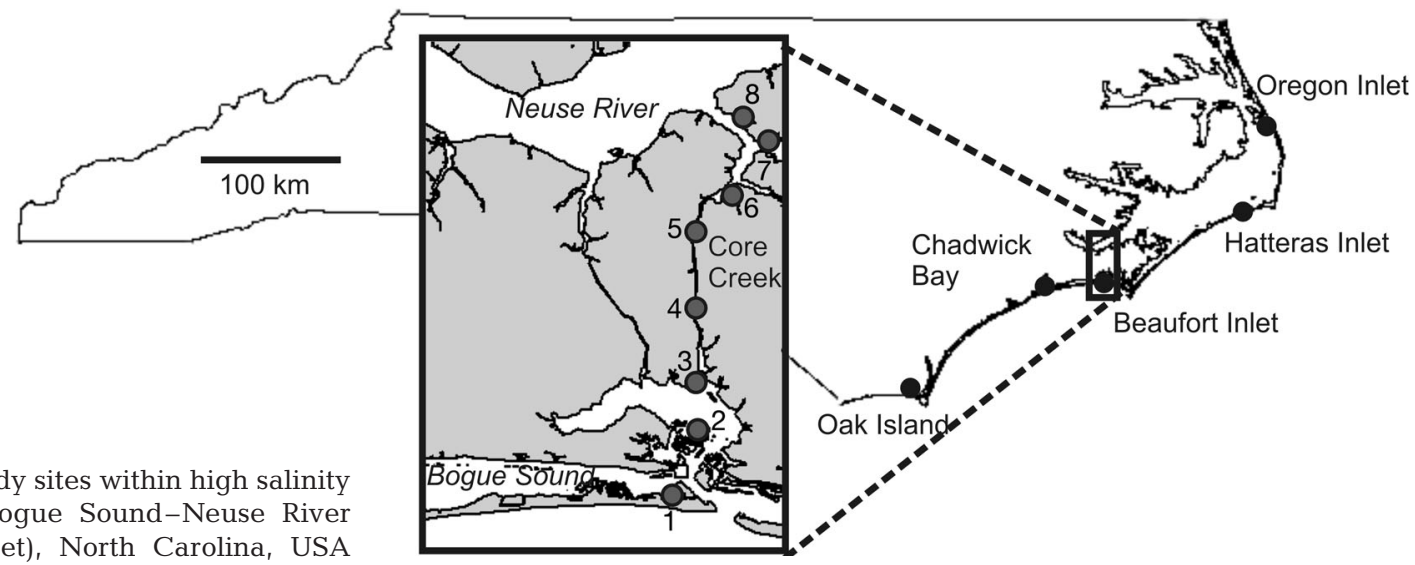


wide and $2.6 \mathrm{~m}$ long and held 5 oyster bags $(0.85 \times$ $0.45 \times 0.05 \mathrm{~m}$ ) of $9 \mathrm{~mm}$ polypropylene mesh. Initially, each rack contained only 2 bags of 100 larger (40 to $50 \mathrm{~mm})$ C. ariakensis from the summer 2003 spawn. Two bags of 100 smaller (15 to $25 \mathrm{~mm}$ ) C. ariakensis seed from the 2004 cohort were added to each rack on 1 October, following observations of greater mortality among smaller than larger $C$. ariakensis in other experiments at nearby Hoop Pole Creek.

On 16 August 2004, samples of 30 large oysters were collected from a single oyster bag at each position. An additional 30 oysters were collected from each of these bags and a single bag of small oysters at each position on 27 October and 16 November 2004. These intervals of sampling were based on the 2 mo infection time of Crassostrea ariakensis deployed into Bogue Sound in 2003 (see Burreson et al. 2004). On each sampling date, we measured the salinity at each position using a portable refractometer. Bags of undisturbed oysters were used to estimate \% cumulative mortality of each cohort at each position. All measurements of salinity and collections of oysters were conducted at low tide when racks were most accessible, because there is little difference between salinities collected on one low tide and the following high tide at these sites (Wells 1961).

To generate insight into the North Carolina coastwide distribution of Bonamia sp., we deployed larger, 2003 cohort Crassostrea ariakensis from Swan Quarter and smaller, 2004 cohort seed at high salinity (>25 ppt) sites spanning nearly the entire range of North Carolina's coast (Fig. 1) on 22 to 24 September 2004. We limited sites to high salinity because Bogue Sound, the only location at which the parasite has previously been detected, typically has a salinity of 30 to $35 \mathrm{ppt}$. All sites were selected to have a high flow and proximal hard bottom because these conditions are required for growth of the native oyster Ostreola equestris, which is a potential reservoir for the parasite. Oysters were deployed using the rack-and-bag system described above. One of the sites (Oregon Inlet) was located to the north of the Cape Hatteras faunal divide, and 4 sites (Hatteras Inlet, Beaufort Inlet, Chadwick Bay, Oak Island) were located to the south. The Beaufort Inlet site was located opposite Morehead City Port, only several kilometres from the Bogue Sound site where the parasite had previously been detected. Samples of 30 oysters from a single bag of each cohort were collected from each site between 29 and 31 October, and between 1 and 2 December 2004. As with sampling along the salinity gradient, oysters in additional, undisturbed bags were used to estimate \% cumulative mortality on each sampling date, and salinity was measured using a refractometer.

After collection, oysters were placed on ice and shipped live to VIMS. Upon arrival, the shell height of each oyster was measured, shucked, and a small ( $\sim 3$ to $5 \mathrm{~mm}^{3}$ ) piece of gill and visceral mass tissue was removed and placed into $95 \%$ ethanol. Remaining tissues were fixed in Davidson's solution (Shaw \& Battle 1957) for standard histopathology. DNA was extracted from the ethanol-preserved tissue using a QIAamp DNA Kit (QIAGEN) and Bonamia-generic PCR was performed (Carnegie et al. 2000). Positive Bonamiageneric amplifications were always followed by assays specific to each local Bonamia sp. The assay specific to the Crassostrea ariakensis-pathogenic Bonamia sp. was performed in a $25 \mu \mathrm{l}$ volume that included 200 to $250 \mathrm{ng}$ genomic DNA, $1 \times$ PCR buffer, $1.5 \mathrm{mM} \mathrm{MgCl}_{2}$, $0.2 \mathrm{mM}$ deoxyribonucleotide triphosphate (dNTP), $0.4 \mu \mathrm{g} \mathrm{\mu l}^{-1}$ bovine serum albumin, $0.5 \mu \mathrm{M}$ primers (forward = CaBon146F: 5'-ATACGTGACAAACCCT GCTCG-3'; reverse $=$ CaBon461R: 5' - TTCCGAATAGGCAACCGAAG-3'), and AmpliTaq polymerase at $0.024 \mathrm{U} \mathrm{Hl}^{-1}$ (Applied Biosystems). Temperature cycling began with a 4 min initial denaturation at $94^{\circ} \mathrm{C}$, which was followed by 35 cycles of denaturation at $94^{\circ} \mathrm{C}$ for $30 \mathrm{~s}$, annealing at $62^{\circ} \mathrm{C}$ for $30 \mathrm{~s}$, and extension at $72^{\circ} \mathrm{C}$ for $1.5 \mathrm{~min}$, with a final extension at $72^{\circ} \mathrm{C}$ for $5 \mathrm{~min}$. The assay for the second local Bonamia sp. was performed as described in Carnegie et al. (2006). Products were electrophorized on agarose gels, poststained with ethidium bromide, and evaluated under UV light. Oysters shown to be Bonamia spp.-positive by PCR were evaluated histopathologically.

\section{RESULTS}

Data from both components of this study suggested that the Crassostrea ariakensis-pathogenic Bonamia sp. was not broadly distributed beyond Bogue Sound. Along the Bogue Sound-Neuse River salinity gradient we detected Bonamia sp. only at high salinity sites close to Morehead City Port. On 27 October, $47 \%$ of seed at Site 1 (Bogue Sound, 32 to 36 ppt salinity) and $3 \%$ of large oysters at Site 2 (Newport River, 18 to $35 \mathrm{ppt}$ ) were PCR-positive for the parasite (Table 2). On 16 November, Bonamia sp. was detected only at Site 1 in both seed (30\%) and larger transplants (3\%). Every PCR-positive oyster was confirmed by histopathology to be infected by Bonamia sp., with most infections multifocal to systemic, and moderate to heavy in intensity.

Deployments of large and small Crassostrea ariakensis at 5 high salinity sites across North Carolina similarly failed to detect $C$. ariakensis-pathogenic Bonamia sp. beyond Bogue Sound. Bonamia sp. was not detected in large or small oysters at Oregon Inlet, Hatteras Inlet, Chadwick Bay, or Oak Island. At Beaufort Inlet, just 1 or $2 \mathrm{~km}$ from the site of the parasite's origi- 
nal discovery, the parasite was detected in $46 \%$ of $C$. ariakensis seed on 27 October but in none of the larger oysters (Table 3 ). In early December the parasite was detected in $17 \%$ of large oysters and $23 \%$ of small oysters screened (Table 3). Once again, every PCRpositive oyster was confirmed by histopathology to be infected by Bonamia sp. The majority of infections were light and multifocal in October, but most were heavy and systemic by December.

Infection prevalence was generally greater among smaller than larger oysters. Examination on 16 August of 30 large oysters from each position along the salinity gradient failed to detect the parasite. On 27 October, sampling at Site 1 did not detect the parasite in any of the large oysters, despite 14 of the seed oysters at this site screening positive for Bonamia sp. On 16 November, 1 large oyster was positive for Bonamia sp. at Site 1 while 9 oyster seeds at this site were infected. Both October and December sampling revealed a greater prevalence of Bonamia sp. among small than large oysters at the Beaufort Inlet site (Table 3). The presence of infection in older oysters at Site 2 in October was the only time that older oysters were found to be infected while younger ones were not.
Mortality of oysters was greatest at Bonamia sp.affected sites. Along the salinity gradient, cumulative mortality of oysters at Site 1 (the site of highest Bonamia sp. prevalence) was over 3 times that of any other site (Table 2). Similarly, mortality of large and small oysters was greater at Beaufort Inlet than at Oregon Inlet, Hatteras Inlet, Chadwick Bay, or Oak Island. Mortality was greater among larger oysters than among smaller oysters at Site 1 on the salinity gradient; however, larger oysters had been in the water several weeks longer (Table 3).

\section{DISCUSSION}

The identification in 2003 of a Crassostrea ariakensis-pathogenic Bonamia sp. in Bogue Sound, North Carolina, raised questions on the economic and ecological risk of introducing the non-native Suminoe oyster to the mid-Atlantic coast. The current and potential distribution of Bonamia sp. beyond Bogue Sound became a matter of immediate concern, as this knowledge would be critical in assessing of the risk that the pathogen represents to $C$. ariakensis, and the

Table 2. Deployment sites along Bogue Sound-Core Creek salinity gradient, cumulative mortality, and prevalence of Bonamia sp. in surviving Crassostrea ariakensis oysters. Large oysters (40 to $50 \mathrm{~mm}$ ), deployed 23 July 2004, were sampled 3 times and small oysters (15 to $25 \mathrm{~mm}$ ), deployed 1 October 2004, were sampled 2 times in fall 2004. Data from Site 4 is incomplete due to removal of those oysters. Bonamia sp. prevalence: no. infected oysters/no. oysters examined. See Fig. 1 for locations of Sites 1 to 8

\begin{tabular}{|c|c|c|c|c|c|c|c|c|c|c|c|c|c|c|}
\hline \multirow[t]{3}{*}{ Site } & \multirow{3}{*}{$\begin{array}{l}\text { Latitude } \\
\qquad\left({ }^{\circ} \mathrm{N}\right)\end{array}$} & \multirow{3}{*}{$\begin{array}{l}\text { Longitude } \\
\qquad\left({ }^{\circ} \mathrm{W}\right)\end{array}$} & \multicolumn{2}{|c|}{ Salinity (ppt) } & \multicolumn{5}{|c|}{ Cumulative mortality (\%) } & \multicolumn{5}{|c|}{ Bonamia sp. prevalence } \\
\hline & & & Range & Mean & 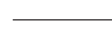 & - Large & & - Smo & all —_ & $\longrightarrow$ & - Large & & - Sma & 111 \\
\hline & & & & $(1 \mathrm{SE})$ & 16 Aug & 27 Oct & $16 \mathrm{Nov}$ & 27 Oct & $16 \mathrm{Nov}$ & 16 Aug & 27 Oct & $16 \mathrm{Nov}$ & 27 Oct & $16 \mathrm{Nov}$ \\
\hline 1 & $34^{\circ} 42^{\prime} 07^{\prime \prime}$ & $76^{\circ} 42^{\prime} 13^{\prime \prime}$ & $32-36$ & 33(1) & 24 & 38 & 38 & 13 & 31 & $0 / 30$ & $0 / 30$ & $1 / 30$ & $14 / 30$ & 9/30 \\
\hline 2 & $34^{\circ} 44^{\prime} 53^{\prime \prime}$ & $76^{\circ} 41^{\prime} 08^{\prime \prime}$ & $18-35$ & $28(3)$ & 5 & 6 & 8 & 0 & 2 & $0 / 30$ & $3 / 30$ & $0 / 30$ & $0 / 30$ & $0 / 30$ \\
\hline 3 & $34^{\circ} 46^{\prime} 17^{\prime \prime}$ & $76^{\circ} 41^{\prime} 17^{\prime \prime}$ & $22-35$ & $27(3)$ & 1 & 2 & 2 & 0 & 0 & $0 / 30$ & $0 / 29$ & $0 / 30$ & $0 / 30$ & $0 / 30$ \\
\hline 4 & $34^{\circ} 49^{\prime} 11^{\prime \prime}$ & $76^{\circ} 41^{\prime} 22^{\prime \prime}$ & $20-35$ & $23(3)$ & 2 & \multicolumn{4}{|c|}{ NOT AVAILABLE } & $0 / 30$ & \multicolumn{4}{|c|}{ NOT AVAILABLE } \\
\hline 5 & $34^{\circ} 53^{\prime} 10^{\prime \prime}$ & $76^{\circ} 41^{\prime} 17^{\prime \prime}$ & $12-29$ & $19(4)$ & 1 & 7 & 9 & 2 & 3 & $0 / 30$ & $0 / 30$ & $0 / 30$ & $0 / 30$ & $0 / 30$ \\
\hline 6 & $34^{\circ} 56^{\prime} 03^{\prime \prime}$ & $76^{\circ} 39^{\prime} 28^{\prime \prime}$ & $10-25$ & $16(3)$ & 0 & 3 & 3 & 1 & 2 & $0 / 30$ & $0 / 30$ & $0 / 30$ & $0 / 30$ & $0 / 30$ \\
\hline 7 & $34^{\circ} 54^{\prime} 03^{\prime \prime}$ & $76^{\circ} 40^{\prime} 23^{\prime \prime}$ & $10-25$ & $15(3)$ & 1 & 12 & 12 & 0 & 8 & $0 / 30$ & $0 / 29$ & $0 / 30$ & $0 / 30$ & $0 / 30$ \\
\hline 8 & $34^{\circ} 57^{\prime} 31^{\prime \prime}$ & $76^{\circ} 40^{\prime} 34^{\prime \prime}$ & $8-14$ & $12(1)$ & 1 & 6 & 6 & 0 & 0 & $0 / 30$ & $0 / 29$ & $0 / 30$ & $0 / 30$ & $0 / 30$ \\
\hline
\end{tabular}

Table 3. High salinity sites in North Carolina, cumulative mortality, and prevalence of Bonamia sp. for large (40 to $50 \mathrm{~mm}$ ) and small (15 to $25 \mathrm{~mm}$ ) Crassostrea ariakensis oysters deployed between 22 and 24 September. Oysters were sampled between 29 and 31 October, and between 1 and 2 December 2004. Bonamia sp. prevalence: no. infected oysters/no. oysters examined

\begin{tabular}{|c|c|c|c|c|c|c|c|c|c|c|c|c|}
\hline \multirow[t]{3}{*}{ Site } & \multirow{3}{*}{$\begin{array}{l}\text { Latitude } \\
\left({ }^{\circ} \mathrm{N}\right)\end{array}$} & \multirow{3}{*}{$\begin{array}{l}\text { Longitude } \\
\quad\left({ }^{\circ} \mathrm{W}\right)\end{array}$} & \multicolumn{2}{|c|}{ Salinity (ppt) } & \multicolumn{4}{|c|}{ Cumulative mortality (\%) } & \multicolumn{4}{|c|}{ Bonamia sp. prevalence } \\
\hline & & & \multirow[t]{2}{*}{ Range } & \multirow{2}{*}{$\begin{array}{l}\text { Mean } \\
(1 \mathrm{SE})\end{array}$} & \multicolumn{2}{|c|}{ Large } & \multicolumn{2}{|c|}{ Small } & \multicolumn{2}{|c|}{ Large } & \multicolumn{2}{|c|}{ Small } \\
\hline & & & & & Oct & Dec & Oct & Dec & Oct & Dec & Oct & Dec \\
\hline Oregon Inlet & $35^{\circ} 46^{\prime} 33^{\prime \prime}$ & $76^{\circ} 33^{\prime} 52^{\prime \prime}$ & $32-36$ & $33(1)$ & 1 & 1 & 1 & 2 & $0 / 30$ & $0 / 30$ & $0 / 30$ & $0 / 30$ \\
\hline Hatteras Inlet & $35^{\circ} 11^{\prime} 23^{\prime \prime}$ & $75^{\circ} 47^{\prime} 07^{\prime \prime}$ & $23-27$ & $25(3)$ & 1 & 2 & 1 & 7 & $0 / 30$ & $0 / 30$ & $0 / 30$ & $0 / 30$ \\
\hline Beaufort Inlet & $34^{\circ} 42^{\prime} 07^{\prime \prime}$ & $76^{\circ} 42^{\prime} 13^{\prime \prime}$ & $30-31$ & $31(1)$ & 8 & 17 & 13 & 25 & $0 / 30$ & $5 / 30$ & $13 / 28$ & $7 / 30$ \\
\hline Chadwick Bay & $34^{\circ} 31^{\prime} 36^{\prime \prime}$ & $77^{\circ} 22^{\prime} 34^{\prime \prime}$ & $28-31$ & $30(2)$ & 13 & 13 & 1 & 6 & $0 / 30$ & $0 / 30$ & $0 / 30$ & $0 / 30$ \\
\hline Oak Island & $33^{\circ} 53^{\prime} 43^{\prime \prime}$ & $78^{\circ} 01^{\prime} 54^{\prime \prime}$ & $25-31$ & $28(4)$ & 9 & 13 & 0 & 4 & $0 / 30$ & $0 / 30$ & $0 / 30$ & $0 / 30$ \\
\hline
\end{tabular}


risk that $C$. ariakensis in turn represents to native bivalves to which it might transmit the parasite. Screening of 2 cohorts of $C$. ariakensis deployed across North Carolina failed to detect the parasite at Oregon Inlet, Hatteras Inlet, Chadwick Bay, or Oak Island: all high salinity, well-flushed sites chosen because of their similarity to the Beaufort Inlet site at which Bonamia sp. is known to occur (Burreson et al. 2004). Sampling along an environmental salinity gradient extending from Morehead City Port up into the Neuse River similarly failed to reveal the Bonamia sp. parasite beyond the immediate vicinity of Morehead City Port, despite high salinities and the presence of Ostreola equestris at several sites further upstream. Although it is possible that Bonamia sp. is widespread, but absent or locally scarce at the sites selected outside Bogue Sound, another possible hypothesis is that the introduction of the parasite to Bogue Sound occurred very recently and that the parasite's range is just beginning to expand. Previous deployments of oysters in the Chesapeake Bay and North Carolina, including the Newport River at Morehead City (Calvo et al. 2001, Grabowski et al. 2004), did not result in mortality of the scale observed in 2003, which we now know was the result of Bonamia sp. infection (Burreson et al. 2004). Furthermore, the small subunit (SSU) rDNA sequence of the Bonamia sp. showed a clear affinity to southern hemispheric Bonamia spp. Taken together, these data point to a recent introduction, perhaps through shipping.

Ballast water and outer hulls of ships provide vectors of species introductions along all coastlines and across every ocean (Ruiz et al. 2000). Centres of shipping activity can consequently be considered hot spots for marine invasions (Cohen \& Carlton 1998). Among ports, Morehead City is particularly susceptible to bioinvasions: it receives large volumes of shipping traffic (767 vessels over the last $5 \mathrm{yr}$; North Carolina State Ports Authority [NCSPA], see www.ncports.com), has deep channel basins and berths that permit deballasting in the port (T. Lewis pers. comm.), experiences minimal tidal flushing (Kirby-Smith \& Costlow 1989), and is serviced primarily by bulk carriers that arrive with little or no cargo and full of ballast water (NCSPA). Further, estuarine waters of the adjacent Newport River contain large concentrations of agricultural wastes, chemicals, and urban run-off (KirbySmith \& Costlow 1989). These conditions can reduce abundances of native competitors, and increase invasibility of the system (Ruiz et al. 2000).

Port records indicate that several of the vessels that serviced Morehead City Port over the last 5 yr frequent the Asia-Pacific region. Although Bonamia sp. was first identified in Crassostrea ariakensis in September 2003, consideration of a broader window of shipping activity is relevant because the recent discovery of $C$. ariakensis-pathogenic Bonamia sp. in Ostreola equestris raises the possibility that the parasite was present in low abundance in the native oyster prior to its identification in C. ariakensis. Knowledge of ballast water ecology suggests that the hypothesis of a shipping introduction of C. ariakensis-pathogenic Bonamia sp. is feasible. Walton (1998) found over 100 morpho-species in ballast water entering Morehead City Port from Japan, clearly indicating that organisms from the AsiaPacific region can survive the $40 \mathrm{~d}$ transit. Even ballast water that was supposedly changed in a mid-ocean exchange contained large numbers of morpho-species (Walton 1998).

If Bonamia sp. indeed represents a recent shipping introduction, its spread will be dependent on vectors for transport, availability of suitable hosts, and environmental tolerance of the parasite itself. Due to the location of Morehead City Port along the Atlantic Intracoastal Waterway - a major transport corridor for large barges and recreational vessels travelling between New York and Florida - and the role of the port as a shipping hub for transport within the USA, spread of the parasite via local or regional shipping is conceivable. Indeed, the detection of the parasite in populations of Ostreola equestris at Wilmington, just meters from the Atlantic Intracoastal Waterway, but not further south at Pinellas Point, St Petersburg, Florida (R. B. Carnegie unpubl. data), is suggestive of the spread of the parasite by shipping; however, this would need to be confirmed by molecular genetics. Our failure to detect the Bonamia sp. parasite in waters proximal to Morehead City Port but of less than 20 ppt suggests that salinity may limit distribution of the parasite or an intermediate host.

The other key result of this study relates to Bonamia sp. susceptibility and oyster size. Whereas previous studies suggested that large oysters are more susceptible to Bonamia spp. parasites than small oysters (Montes 1991, Cáceres-Martínez et al. 1995), we found oyster seed $<40 \mathrm{~mm}$ in shell height to be most susceptible; $46 \%$ of Crassostrea ariakensis seed deployed to Beaufort Inlet between 22 and 24 September were positive for Bonamia sp. after $37 \mathrm{~d}$, whereas none of the 1 yr-olds deployed during the same period were Bonamia sp.-positive. A similar pattern of infection was observed at Site 1 on the salinity gradient, where 9 times as many small compared to large oysters were infected by the parasite by the end of the study. At the Beaufort Inlet site, the greater prevalence of Bonamia sp. among small oysters was reflected in the greater cumulative rate of mortality among the small (25\%) than the large $(17 \%)$ oysters. However, at Site 1 on the salinity gradient, mortality was comparable between the 2 cohorts. Only at Site 2 on the salinity gradient 
were Bonamia sp. infections seen among larger, 23 July-deployed $C$. ariakensis (observed 27 October) but never among smaller, 1 October-deployed C. ariakensis. This result, inconsistent with the size-specificity of infection at other sites, may refect fluctuations in salinity. Newport River is subject to dramatically reduced salinities during heavy rainfalls (Wells 1961), and salinity here may have been reduced even below recorded levels (18 ppt) during the several hurricanes and tropical storms of August and September 2004. It is possible that the oysters deployed earlier had acquired pre-patent Bonamia sp. infections when salinities were high before the storms. It appears that Bonamia sp. disappeared from its environmental source or reservoir outside $C$. ariakensis in the Newport River before the smaller oysters were deployed on 1 October.

The results of this study have significant implications for the proposed introduction of Crassostrea ariakensis to the mid-Atlantic coast. Our results suggest that the presently limited distribution of $C$. ariakensis-pathogenic Bonamia sp. may be a result of a recent introduction through Morehead City Port and an inability of the parasite to expand its range into nearby lower salinity waters. In the event of a large-scale $C$. ariakensis introduction, range expansion of the parasite may occur if boat traffic and human-mediated oyster transfers allow the parasite to bypass low salinity barriers. Furthermore, although the present distribution of the parasite appears to be limited by salinity, the low-medium (15 to $25 \mathrm{ppt}$ ) salinity waters of the Pamlico Sound and Chesapeake Bay should not necessarily be viewed as long-term havens from the parasite. Just as climate warming appears to have facilitated recent range expansion of Perkinsus marinus into upper Chesapeake and Delaware Bays (Ford 1996), it may allow future expansion of C. ariakensis-pathogenic Bonamia sp. into previously uninhabitable waters. Nevertheless, because Bonamia sp. infection appears to be limited to small oysters, culture of $C$. ariakensis may be possible by situating hatcheries in Bonamia spp.-free areas and transplanting oysters greater than $40 \mathrm{~mm}$ to higher salinity waters, where growth rates are faster (Calvo et al. 2001, Grabowski et al. 2004, Bishop \& Peterson 2005). Clearly, further research on the risk that Bonamia sp. poses to C. ariakensis aquaculture and the ecology of native species is advised before the introduction proceeds.

Our study demonstrates the benefits of carefully controlled field trials with non-native species prior to their introduction. Because Bonamia sp. is not known to infect the commercially important native oyster Crassostrea virginica, the parasite was only identified as a potential economic threat to, and ecological risk of, the proposed introduction through in-water trials. Although experimental approaches such as ours are not without ecological risks, when designed with careful consideration to ethics and biosecurity they have the power to improve predictions on the likely outcome of introductions (Clark et al. 2001) and limit the likelihood of resultant conservation crises.

Acknowledgements. This study was funded by NOAA's Chesapeake Bay Office, Virginia Sea Grant, North Carolina Sea Grant and the North Carolina General Assembly. It was conducted in compliance with permits from North Carolina Division of Marine Fisheries for the importation and field deployment of non-native shellfish, following federal approval through an environmental impact assessment. Importation of oysters followed guidelines recommended by ICES. We thank M. Marshall of North Carolina Division of Marine Fisheries for assistance with site selection and establishment of research reserves. S. K. Allen Jr. (VIMS) provided triploid Crassostrea ariakensis. J. Braddy and M. Ulery maintained C. ariakensis in North Carolina and collected biological and physical data. Histopathology was performed at VIMS Shellfish Pathology Laboratory; S. Denny and L. Martin conducted histological processing and R. Crockett the Bonamia sp. evaluations. Suggestions from 4 anonymous reviewers improved the quality of this manuscript.

\section{LITERATURE CITED}

Barber BJ, Davis C (1994) Prevalence of Bonamia ostreae in Ostrea edulis populations in Maine. J Shellfish Res 13:298

Bishop MJ, Peterson CH (2005) Constraints to Crassostrea ariakensis aquaculture: season and method of culture strongly influence success of grow-out. J Shellfish Res 24:497-502

Branch GM, Steffani CN (2004) Can we predict the effects of alien species? A case-history of the invasion of South Africa by Mytilus galloprovincialis (Lamarck). J Exp Mar Biol Ecol 300:189-215

Burreson EM, Stokes NA, Carnegie RB, Bishop MJ (2004) Bonamia sp. (Haplosporidia) found in non-native oysters, Crassostrea ariakensis, in Bogue Sound, North Carolina. J Aquat Anim Health 16:1-9

Cáceres-Martinez J, Robledo JAF, Figueras A (1995) Presence of Bonamia and its relation to age, growth rates and gonadal development of the flat oyster, Ostrea edulis, in the Ria de Vigo, Galicia (NW Spain). Aquaculture 130:15-23

Calvo GW, Luckenbach MW, Allen SK Jr, Burreson EM (2001) A comparative field study of Crassostrea ariakensis (Fujita 1913) and Crassostrea virginica (Gmelin 1791) in relation to salinity in Virginia. J Shellfish Res 20:221-229

Carnegie RB, Barber BJ, Culloty SC, Figueras AJ, Distel DL (2000) Development of a PCR assay for detection of the oyster pathogen Bonamia ostreae and support for its inclusion in the Haplosporidia. Dis Aquat Org 42:199-206

Carnegie RB, Stokes NA, Audemard C, Burreson EM (2005) Bonamiasis in the crested oyster Ostrea equestris in North Carolina, USA. J Shellfish Res 24:644

Carnegie RB, Burreson EM, Hine PM, Stokes NA, Audemard C, Bishop MJ, Peterson CH (2006) Bonamia perspora n. sp. (Haplosporidia), a parasite of the oyster Ostreola equestris, is the first Bonamia species known to produce spores. J Eukaryot Microbiol 53:1-14

Clark JS, Carpenter SR, Barber M, Collins S and 13 others (2001) Ecological forecasts: an emerging imperative. Science 293:657-660 
Cohen AN, Carlton JT (1998) Accelerating invasion rate in a highly invaded estuary. Science 279:555-558

Ehrlich PR (1989) The attributes of invaders and invasion processes: vertebrates. In: Mooney HA, Drake JA (eds) SCOPE 37. Biological invasions, a global perspective. John Wiley \& Sons, Chichester, p 315-328

Ford SE (1996) Range extension by the oyster parasite Perkinsus marinus into the northeastern United States: response to climate change? J Shellfish Res 15:45-56

Frankenberg D (1995) North Carolina blue ribbon advisory council on oysters. Final report and recommendations. North Carolina Department of Environment and Natural Resources, Raleigh, NC

Friedman CS, Perkins FO (1994) Range extension of Bonamia ostreae to Maine, USA. J Invertebr Pathol 64:179-181

Galtsoff PS, Merrill AS (1962) Notes on shell morphology, growth, and distribution of Ostrea equestris Say. Bull Mar Sci Gulf Caribb 12:234-244

Grabowski JH, Peterson CH, Powers SP, Gaskill D, Summerson HC (2004) Growth and survivorship of non-native (Crassostrea gigas and Crassostrea ariakensis) vs. native eastern oysters (Crassostrea virginica). J Shellfish Res 23: 781-793

Grosholz ED, Ruiz GM, Dean CA, Shirley KA, Maron JL, Connors PG (2000) The impacts of a non-indigenous marine predator in a California bay. Ecology 81:1206-1224

Kirby-Smith WW, Costlow JD (1989) The Newport River estuarine system, UNC Sea Grant College Publication UNCSG-89-04. Duke University Marine Laboratory, Beaufort, $\mathrm{NC}$

Montes J (1991) Lag time for the infestation of flat oyster

Editorial responsibility: Howard Browman (Associate Editorin-Chief), Storebø, Norway
(Ostrea edulis L.) by Bonamia ostreae in estuaries of Galicia (N.W. Spain). Aquaculture 93:235-239

NRC (National Research Council of the National Academy of Sciences) (2004) Non-native oysters in Chesapeake Bay. The National Academies Press, Washington, DC

Rothschild BJ, Ault JS, Goulletquer P, Héral M (1994) Decline of the Chesapeake Bay oyster population: a century of habitat destruction and overfishing. Mar Ecol Prog Ser 111:29-39

Ruiz GM, Fofonoff PM, Carlton JT, Wonham MJ, Hines AH (2000) Invasion of coastal marine communities in North America: Apparent patterns, processes, and biases. Annu Rev Ecol Syst 31:481-531

Shaw BL, Battle HI (1957) The gross and microscopic anatomy of the digestive tract of the oyster Crassostrea virginica (Gmelin). Can J Zool 35:325-346

Stachowicz JJ, Whitlatch RB, Osman RW (1999) Species diversity and invasion resistance in a marine ecosystem. Science 286:1577-1579

Stachowicz JJ, Fried H, Osman RW, Whitlatch RB (2002) Biodiversity, invasion resistance, and marine ecosystem function: reconciling pattern and process. Ecology 83: $2575-2590$

Walton HP (1998) Synthesizing science and policy to reduce the probability of marine biological invasions due to ballast water discharge in the Port of Morehead City, North Carolina. MEM thesis, Duke University, Durham, NC

Wells HW (1961) The fauna of oyster beds, with special reference to the salinity factor. Ecol Monogr 31:239-266

Williamson MH, Fitter A (1996) The characters of successful invaders. Biol Conserv 78:163-170

Submitted: January 5, 2006; Accepted: April 20, 2006

Proofs received from author(s): October 11, 2006 